\title{
Physiological potential of maize seeds submitted to different treatments and storage periods ${ }^{1}$
}

\author{
Giovanna Emanuelle Gonçalves Mariucci ${ }^{* 2}$, Andréia Kazumi Suzukawa², \\ Alessandro Lucca Braccini², Carlos Alberto Scapim², Luiz Henrique da Silva Lima², \\ Priscila Angelotti ${ }^{2}$, Raissa Marrafon Ponce ${ }^{3}$, Danilo Cesar Volpato Marteli ${ }^{2}$
}

\begin{abstract}
The aim of the study was to evaluate seed germination and vigor of maize subjected to different products and storage periods. The experimental design was completely randomized in a split plot on time. In the plots were distributed nine treatments: an untreated control, one treatment called "standard treatment", with addition of fungicide (fludioxonil + metalaxyl-M) and insecticide (thiamethoxam). From the standard treatment, six treatments with combinations of inoculant (Azospirillum brasilense), micronutrients (nitrogen + potassium + zinc + boron + copper + iron + manganese + molibdenium) and bioregulator. Lastly, a treatment called "complete treatment" including all products. In subplots the storage periods of zero, 15, 30, 45, 60 and 90 days were evaluated. Seed vigour of maize was reduced by seed treatments and storage. Micronutrients addition resulted in higher fitotoxicity in comparison to the addition of other products, regardless of storage period. The treatment with the combination of fungicide, insecticide and inoculant proved to be feasible, and was the most promising seed treatments. None of the studied treatments affected the germination in up to 45 days of storage, however the complete treatment with $3200 \mathrm{~mL} .100 \mathrm{~kg}^{-1}$ reduced seed vigour.
\end{abstract}

Index terms: Zea mays, chemical treatment, germination, vigour.

\section{Potencial fisiológico de sementes de milho submetidas a diferentes tratamentos e períodos de armazenamento}

\begin{abstract}
RESUMO - O objetivo do trabalho foi avaliar a germinação e vigor das sementes de milho submetidas a diferentes produtos e períodos de armazenamento. O delineamento experimental foi inteiramente casualizado em esquema de parcelas subdivididas no tempo. Na parcela foram distribuídos nove tratamentos: uma testemunha não tratada, um tratamento denominado de "tratamento padrão", com adição de fungicida (fludioxonil + metalaxyl-M) e inseticida (thiamethoxam). A partir do tratamento padrão, seis tratamentos com combinações de inoculante (Azospirillum brasilense), micronutrientes (nitrogen + potassium + zinc + boron + copper + iron + manganese + molibdenium) e biorregulador. Por fim, um tratamento denominado de "tratamento completo", incluindo todos os produtos. Na subparcela, os períodos de armazenamento 0, 15, 30, 45, 60 e 90 dias foram avaliados. O vigor das sementes de milho foi reduzido pelos tratamentos de sementes e pelo armazenamento. A adição de micronutrientes resultou em maior fitotoxicidade em comparação à adição de outros produtos, independente do período de armazenamento. $\mathrm{O}$ uso de fungicida, inseticida e inoculante se mostram viáveis, como os mais promissores tratamentos de sementes. Nenhum dos tratamentos estudados afetaram a germinação até 45 dias de armazenamento, porém o tratamento completo, com $3200 \mathrm{~mL} .100 \mathrm{~kg}^{-1}$ reduziu o vigor de sementes.
\end{abstract}

Termos para indexação: Zea mays, tratamento químico, germinação, vigor.

\section{Introduction}

Maize seeds are routinely treated, since the advantages of using protected seeds are undeniable. However, the contact of

${ }^{1}$ Submitted on $08 / 25 / 2017$. Accepted on 12/21/2017.

${ }^{2}$ Departamento de Agronomia, Universidade Estadual de Maringá, Av. Colombo, 5790, 87020-900 - Maringá, PR, Brasil. the seed with fungicides, insecticides, micronutrients, growth regulators, polymers, drying powder and even water itself increases the risks of reducing the physiological quality of seeds, to a greater or lesser degree depending on the agent

${ }^{3}$ Departamento de Agronomia, Universidade Estadual de Londrina, Rod. Celso Garcia Cid, km 380, 86057-970 - Londrina, PR, Brasil.

*Corresponding author < mariuccigi@gmail.com> 
used (Deuner et al., 2014).

Several studies involving seed treatment reports the efficiency of products, separating them by purpose, whether they are insecticides (Dan et al., 2011), fungicides (Alves and Juliatti, 2010), bioregulators (Silva et al., 2008), fertilizers (Dias et al., 2015) and some combinations of them (Avelar et al., 2011). However, the constant search for new options for chemical treatment is necessary.

The fungicide Maxin ${ }^{\circledR}$ was efficient in preserving the vigour of maize seeds for up to three months of storage, besides reducing the mycelial growth (Resende et al., 2005). However, treatment of maize seeds with fluquinconazole on sowing day reduced the emergence percentage by $2.4 \%$ (Alves and Juliatti, 2010).

When evaluating seeds of three maize hybrids, Tonin et al. (2014) observed a reduction in seed vigour treated with thiamethoxam for up to 270 days of storage. Castro et al. (2008) observed greater vigour of soybean seeds treated with imidacloprid. This indicates that results are dependent on plant species.

Seed treatment has also become an alternative for application of micronutrients. Operational ease, low cost, greater uniformity of distribution, as well as availability of nutrients in the initial stage of plant growth, are some of the advantages. Levels of zinc and copper in plant tissues are higher in the initial growth phase (Farooq et al., 2012). Increased yield of maize was obtained when seed treatment with zinc sulfate was used (Harris et al., 2007). Doses of copper did not affect physiological quality of seeds during four months of storage (Dias et al., 2015). This practice is a viable and effective alternative for supplying these elements to maize plants.

In seed treatment with Stimulate ${ }^{\circledR}$, for the inbred line L57, the product reduced germination by $38 \%$; however, for the hybrid GNZ 2004 there was a 29\% increase in germination (Silva et al., 2008). In high and medium vigour maize seeds, lower intensity in the reduction of vigour during 180 days of storage was observed in lots of high vigour. In medium vigour lots, the major benefits of the bioregulator occurred within 60 days of storage (Dan et al., 2014).

In seed processing units, it is common to adopt anticipated treatment, before bagging or when the seeds are delivered to the grower. However, anticipated treatment can cause problems, such as a possible phytotoxic effect. Studies concerning chemical treatment of seeds are usually carried out on the efficiency of isolated products. However, information on the effect of combination of products and their respective spray volumes on the physiological quality of maize seeds is scarce in the literature. Furthermore, storage influence on this type of seed treatment has been little studied.

The hypothesis of the study is the increasing number of phytosanitary products added to the chemical treatment have a negative influence on the physiological quality of the maize seeds, as well as the spray volume resulting from these combinations, and is aggravated by storage. The aim of this work was to evaluate the physiological potential of maize seeds submitted to different combinations of products and spray volumes in stored seeds.

\section{Material and Methods}

The evaluations of seeds physiological quality were carried out at the Seed Technology Laboratory of the Applied Research Center for Agriculture, of the Agricultural Sciences Center of State University of Maringá.

The study involved nine seed treatments: an untreated control (T1); a treatment called "standard treatment" (T2), which included fungicide and insecticide; from the standard treatment, six treatments included combinations between inoculant, micronutrients and bioregulator and finally, a treatment called "complete treatment" (T9), which included the addition of all products, simulating a situation of high investment in seed treatment (Table 1).

The products used in the present study were the fungicide Fludioxonil + Metalaxyl - M (Maxim XL ${ }^{\circledR}, 0.15$ L. $100 \mathrm{~kg}^{-1}$ of seeds), the insecticide Thiametoxam (Cruiser $350 \mathrm{FS}^{\circledR}, 0.6 \mathrm{~L}$. $100 \mathrm{~kg}^{-1}$ of seeds), the inoculant with Azospirillum brasilense (AzoTotal ${ }^{\circledR}, 0.4 \mathrm{~L} .100 \mathrm{~kg}^{-1}$ of seeds), the liquid fertilizer containing nitrogen, potassium, zinc, boron, copper, iron, manganese and molybdenum (Awaken ${ }^{\circledR} 16-0-2,0.8$ L. $100 \mathrm{~kg}^{-1}$ of seeds) and the bioregulator containing kinetin, gibberellic acid and 4-indole 3-butyric acid (Stimulate ${ }^{\circledR}, 1.25$ L. $100 \mathrm{~kg}^{-1}$ of seeds).

Seeds of commercial hybrid maize 'CD 324 PRO' were used, which received different spray volumes resulting from the combinations of products used. Seed coating was done manually using $3 \mathrm{~kg}$ of seeds for each treatment, in plastic bags. Agitation was done until complete distribution of products and total coating of seeds, with subsequent drying in the shade.

After treatment, part of the seeds were submitted to initial evaluations (period zero), while the other parts were packed in kraft paper bags and stored under laboratory conditions. The following evaluations were performed at 15, 30, 45, 60 and 90 days after initiating storage:

Germination test: Four subsamples of 50 seeds for each treatment were used, according to the criteria established in the Rules for Seed Testing (Brasil, 2009). The evaluation was performed at seven days, computing the percentage of normal seedlings. Normal seedlings showed primary root longer than $9 \mathrm{~cm}$ and shoot higher than $5 \mathrm{~cm}$ and presence of at least two secondary roots. 
Table 1. Scheme of the seed treatments consisting of different combinations of products and respective spray volumes.

\begin{tabular}{|c|c|c|c|c|c|c|}
\hline N. & \multicolumn{5}{|c|}{ Seed Treatment } & $\begin{array}{c}\text { Spray Volume } \\
\text { (L. } 100 \mathrm{~kg}^{-1} \text { of seeds) }\end{array}$ \\
\hline $\mathrm{T} 1$ & \multicolumn{2}{|c|}{ Control } & & & & 0.00 \\
\hline $\mathrm{T} 2$ & Fungicide $^{1}$ & Insecticide $^{2}$ & (Standard) & & & 0.75 \\
\hline T3 & Fungicide $^{1}$ & Insecticide $^{2}$ & Inoculant $^{3}$ & & & 1.15 \\
\hline $\mathrm{T} 4$ & Fungicide $^{1}$ & Insecticide $^{2}$ & & Micronutrients ${ }^{4}$ & & 1.55 \\
\hline T5 & Fungicide $^{1}$ & Insecticide $^{2}$ & & & Bioregulator $^{5}$ & 2.00 \\
\hline T6 & Fungicide $^{1}$ & Insecticide $^{2}$ & Inoculant $^{3}$ & Micronutrients ${ }^{4}$ & & 1.95 \\
\hline $\mathrm{T} 7$ & Fungicide $^{1}$ & Insecticide $^{2}$ & Inoculant $^{3}$ & & Bioregulator $^{5}$ & 2.40 \\
\hline T8 & Fungicide $^{1}$ & Insecticide $^{2}$ & & Micronutrients ${ }^{4}$ & Bioregulator $^{5}$ & 2.80 \\
\hline T9 & Fungicide $^{1}$ & Insecticide $^{2}$ & Inoculant $^{3}$ & Micronutrients ${ }^{4}$ & Bioregulator $^{5}$ & 3.20 \\
\hline
\end{tabular}

${ }^{1}$ Maxim XL ${ }^{\circledR}$ (Fludioxonil + Metalaxyl-M) 0.15 L. $100 \mathrm{~kg}^{-1}$ of seeds.

${ }^{2} \mathrm{Cruiser}^{\circledR}$ (Thiamethoxam) 0.60 L. $100 \mathrm{~kg}^{-1}$ of seeds.

${ }^{3}$ AzoTotal ${ }^{\circledR}$ (Azospirillum brasilense) 0.40 L. $100 \mathrm{~kg}^{-1}$ of seeds.

${ }^{4}$ Awaken ${ }^{\circledR}$ 16-0-2 (nitrogen + potassium + zinc + boron + copper + iron + manganese + molibdenium) $0.80 \mathrm{~L} .100 \mathrm{~kg}^{-1}$ of seeds.

${ }^{5}$ Stimulate ${ }^{\circledR}$ (kinetin + gibberellic acid + 4-indole 3-butyric acid), $1.25 \mathrm{~L} .100 \mathrm{~kg}^{-1}$ of seeds.

Modified cold test: The test was conducted similarly to the germination test. However, the rolls were wrapped in plastic bags, remaining in a germination chamber at $10 \pm$ $1{ }^{\circ} \mathrm{C}$ for seven days. Rolls were then taken to a germinator at $25 \pm 1{ }^{\circ} \mathrm{C}$ for four more days (Barros et al., 1999). The percentage of normal seedlings followed the same criteria for the germination test (Brasil, 2009).

Seedling length: The test was conducted as described for the germination test, remaining for four days. Five subsamples of 20 seeds were used for each treatment. Results were expressed in $\mathrm{cm}$ seedling ${ }^{-1}$ (Nakagawa, 1999).

Emergence speed index: The test was conducted in a greenhouse with four subsamples of 50 seeds for each treatment, in trays containing washed and sterilized sand. Seedlings were counted daily. The results were expressed in the emergence speed index, according to the equation proposed by Maguire (1962).

The experimental design was a completely randomized, with split-plot in time, with four or five replications, according to the variable analyzed. The untreated control and the eight treatments of seeds and spray volumes were distributed in the plots. In the subplots, storage periods of $0,15,30,45$, 60 and 90 days were evaluated. For comparison among the seed treatments, non-orthogonal contrasts were established (Table 2) and submitted to the " $\mathrm{t}$ " test of Bonferroni. The regression analysis was used to verify the fit of polynomial models (linear and quadratic) for the dependent variables, as a function of the storage periods.

\section{Results and Discussions}

The interaction between seed treatment and storage period was significant for all analyzed variables: germination test (GT), seedling length (SL), modified cold test (CT) and emergence speed index (ES). The study of the contrasts allowed to isolate the effect of products, in order to investigate which products influenced the physiological potential of seeds of the hybrid maize 'CD 324 PRO' (Tables 3 and 4).

The comparison of the control with the other treatments, observed through the $\mathrm{C} 1$ contrast, indicated that, on average, significant differences $(\mathrm{p}<0.05)$ were observed for the variables seedling length (Table 3), modified cold test and emergence

Table 2. Non-orthogonal contrasts for mean comparison of seed treatments.

\begin{tabular}{|c|c|c|}
\hline $\mathrm{C} 1$ & $\operatorname{ctrl}^{1} v s$ all $=$ & $\begin{array}{c}8 \mathrm{~T} 1-\mathrm{T} 2-\mathrm{T} 3-\mathrm{T} 4-\mathrm{T} 5-\mathrm{T} 6- \\
\mathrm{T} 7-\mathrm{T} 8-\mathrm{T} 9\end{array}$ \\
\hline $\mathrm{C} 2$ & $\operatorname{ctrl} v s \operatorname{std}^{2}=$ & $\mathrm{T} 1-\mathrm{T} 2$ \\
\hline $\mathrm{C} 3$ & $\operatorname{ctrl} v s \mathrm{cplt}^{3}=$ & $\mathrm{T} 1-\mathrm{T} 9$ \\
\hline $\mathrm{C} 4$ & $\operatorname{std} v s\left(\operatorname{std}+\mathrm{I}^{1}\right)=$ & $\mathrm{T} 2-\mathrm{T} 3$ \\
\hline $\mathrm{C} 5$ & $\operatorname{std} v s\left(\operatorname{std}+\mathrm{M}^{1}\right)=$ & $\mathrm{T} 2-\mathrm{T} 4$ \\
\hline C6 & $\operatorname{std} v s\left(\operatorname{std}+\mathrm{B}^{1}\right)=$ & $\mathrm{T} 2-\mathrm{T} 5$ \\
\hline $\mathrm{C} 7$ & $(\operatorname{std}+\mathrm{I}) v s(\operatorname{std}+\mathrm{I}+\mathrm{M})=$ & $\mathrm{T} 3-\mathrm{T} 6$ \\
\hline $\mathrm{C} 8$ & $(\operatorname{std}+\mathrm{I}) v s(\operatorname{std}+\mathrm{I}+\mathrm{B})=$ & $\mathrm{T} 3-\mathrm{T} 7$ \\
\hline $\mathrm{C} 9$ & $(\operatorname{std}+\mathrm{M}) v s(\operatorname{std}+\mathrm{I}+\mathrm{M})=$ & $\mathrm{T} 4-\mathrm{T} 6$ \\
\hline $\mathrm{C} 10$ & $(\operatorname{std}+\mathrm{M}) v s(\operatorname{std}+\mathrm{M}+\mathrm{B})=$ & $\mathrm{T} 4-\mathrm{T} 8$ \\
\hline $\mathrm{C} 11$ & $(\mathrm{std}+\mathrm{B}) v s(\mathrm{std}+\mathrm{I}+\mathrm{B})=$ & $\mathrm{T} 5-\mathrm{T} 7$ \\
\hline $\mathrm{C} 12$ & $(\mathrm{std}+\mathrm{B}) v s(\mathrm{std}+\mathrm{M}+\mathrm{B})=$ & $\mathrm{T} 5-\mathrm{T} 8$ \\
\hline $\mathrm{C} 13$ & $(\mathrm{std}+\mathrm{I}+\mathrm{M}) v s \mathrm{cplt}=$ & $\mathrm{T} 6-\mathrm{T} 9$ \\
\hline $\mathrm{C} 14$ & $(\mathrm{std}+\mathrm{I}+\mathrm{B}) v s \mathrm{cplt}=$ & $\mathrm{T} 7-\mathrm{T} 9$ \\
\hline $\mathrm{C} 15$ & $(\mathrm{std}+\mathrm{M}+\mathrm{B}) v s \mathrm{cplt}=$ & $\mathrm{T} 8-\mathrm{T} 9$ \\
\hline
\end{tabular}

${ }^{1} \mathrm{ctrl}=$ control; $\mathrm{I}=$ inoculant; $\mathrm{M}=$ micronutrient; $\mathrm{B}=$ bioregulator;

${ }^{2}$ std $=$ standard (fungicide + insecticide);

${ }^{3} \mathrm{cplt}=$ complete (fungicide + insecticide + inoculant + micronutrient + bioregulator) 
speed index (Table 4), for all storage periods, with positive values for the contrasts. In this sense, the addition of any product to the seeds reduced seed vigour, even in period zero, that is, soon after treatment. On the other hand, for the germination variable, differences in the $\mathrm{C} 1$ contrast were not significant until 45 days of storage (Table 3). Thus, it can be inferred that the

Table 3. Results of the contrasts for the germination test (GT) and seedling length (SL), in relation to the nine seed treatments in six storage periods.

\begin{tabular}{|c|c|c|c|c|c|c|c|c|c|c|c|c|}
\hline \multirow{3}{*}{ Contrast } & \multicolumn{12}{|c|}{ Storage (days) } \\
\hline & \multicolumn{2}{|c|}{0} & \multicolumn{2}{|c|}{15} & \multicolumn{2}{|c|}{30} & \multicolumn{2}{|c|}{45} & \multicolumn{2}{|c|}{60} & \multicolumn{2}{|c|}{90} \\
\hline & $\mathrm{GT}$ & SL & GT & SL & GT & SL & GT & SL & GT & SL & GT & $\overline{\mathrm{SL}}$ \\
\hline $\mathrm{C} 1 \operatorname{ctrl}^{1} v s$ all & ns & $33.9^{*}$ & ns & $39.9 *$ & ns & $48.0^{*}$ & ns & $66.3^{*}$ & $61.5^{*}$ & $51.3^{*}$ & $67.0^{*}$ & $62.2 *$ \\
\hline $\mathrm{C} 2 \mathrm{ctrl} v s \mathrm{std}^{2}$ & ns & ns & ns & ns & ns & ns & ns & ns & ns & ns & ns & $4.5^{*}$ \\
\hline $\mathrm{C} 3 \mathrm{ctrl} v s \mathrm{cplt}{ }^{3}$ & ns & $6.3^{*}$ & $8.0^{*}$ & $8.3^{*}$ & $14.5^{*}$ & $8.4^{*}$ & $14.0^{*}$ & $11.4 *$ & $18.5^{*}$ & $8.5^{*}$ & $22.0 *$ & $9.7 *$ \\
\hline $\mathrm{C} 4 \operatorname{std} v s\left(\operatorname{std}+\mathrm{I}^{1}\right)$ & ns & ns & ns & ns & ns & ns & ns & ns & ns & ns & ns & ns \\
\hline $\mathrm{C} 5 \operatorname{std} v s\left(\operatorname{std}+\mathrm{M}^{1}\right)$ & ns & ns & ns & $4.6^{*}$ & ns & ns & ns & $6.0^{*}$ & ns & ns & ns & $4.0^{*}$ \\
\hline $\mathrm{C} 6 \operatorname{std} v s\left(\mathrm{std}+\mathrm{B}^{1}\right)$ & ns & ns & ns & ns & ns & ns & ns & ns & ns & ns & ns & $4.3^{*}$ \\
\hline $\mathrm{C} 7(\mathrm{std}+\mathrm{I}) v s(\mathrm{std}+\mathrm{I}+\mathrm{M})$ & ns & $4.4^{*}$ & $2.5^{*}$ & $4.5^{*}$ & ns & ns & ns & $4.7 *$ & ns & ns & $11.0^{*}$ & ns \\
\hline $\mathrm{C} 8(\operatorname{std}+\mathrm{I}) v s(\mathrm{std}+\mathrm{I}+\mathrm{B})$ & ns & ns & ns & ns & ns & ns & ns & ns & ns & ns & ns & ns \\
\hline $\mathrm{C} 9(\mathrm{std}+\mathrm{M}) v s(\mathrm{std}+\mathrm{I}+\mathrm{M})$ & ns & ns & ns & ns & ns & ns & ns & ns & ns & ns & ns & ns \\
\hline $\mathrm{C} 10(\operatorname{std}+\mathrm{M}) v s(\operatorname{std}+\mathrm{M}+\mathrm{B})$ & ns & $2.0^{*}$ & $7.0^{*}$ & ns & ns & ns & $8.5^{*}$ & ns & $13.5^{*}$ & ns & $14.0^{*}$ & ns \\
\hline $\mathrm{C} 11(\operatorname{std}+\mathrm{B}) v s(\mathrm{std}+\mathrm{I}+\mathrm{B})$ & ns & ns & ns & ns & ns & ns & ns & ns & ns & ns & ns & ns \\
\hline $\mathrm{C} 12(\mathrm{std}+\mathrm{B}) v s(\mathrm{std}+\mathrm{M}+\mathrm{B})$ & ns & $4.8^{*}$ & $8.5^{*}$ & $5.0^{*}$ & $9.0 *$ & ns & $12.5^{*}$ & ns & $18.5^{*}$ & ns & $18.5^{*}$ & ns \\
\hline $\mathrm{C} 13(\mathrm{std}+\mathrm{I}+\mathrm{M}) v s \mathrm{cplt}$ & ns & ns & ns & ns & ns & ns & $9.0 *$ & ns & $10.5^{*}$ & ns & $10.0^{*}$ & ns \\
\hline $\mathrm{C} 14(\mathrm{std}+\mathrm{I}+\mathrm{B}) v s \mathrm{cplt}$ & ns & ns & $7.0^{*}$ & $4.8^{*}$ & $13.5^{*}$ & ns & $14.0^{*}$ & $*$ & $16.0^{*}$ & ns & $20.0^{*}$ & ns \\
\hline $\mathrm{C} 15(\mathrm{std}+\mathrm{M}+\mathrm{B}) v s \mathrm{cplt}$ & ns & ns & ns & ns & ns & ns & ns & ns & ns & ns & ns & ns \\
\hline
\end{tabular}

${ }^{1} \mathrm{ctrl}=$ control; $\mathrm{I}=$ inoculant; $\mathrm{M}=$ micronutrient; $\mathrm{B}=$ bioregulator; ${ }^{2} \mathrm{std}=$ standard (fungicide + insecticide); ${ }^{3} \mathrm{cplt}=$ complete (fungicide + insecticide + inoculant + micronutrient + bioregulator).

*significant at $5 \%$ probability by the Bonferroni " $\mathrm{t}$ " test $(\mathrm{p}<0.05)$; ns non significant $(\mathrm{p}>0.05)$.

Table 4. Results of the contrasts for the modified cold test (CT) and the emergence speed index (ES), in relation to the nine seed treatments in six storage periods.

\begin{tabular}{|c|c|c|c|c|c|c|c|c|c|c|c|c|}
\hline \multirow{3}{*}{ Contrast } & \multicolumn{12}{|c|}{ Storage (days) } \\
\hline & \multicolumn{2}{|c|}{0} & \multicolumn{2}{|c|}{15} & \multicolumn{2}{|c|}{30} & \multicolumn{2}{|c|}{45} & \multicolumn{2}{|c|}{60} & \multicolumn{2}{|c|}{90} \\
\hline & $\mathrm{CT}$ & $\mathrm{ES}$ & $\mathrm{CT}$ & $\mathrm{ES}$ & $\mathrm{CT}$ & $\mathrm{ES}$ & $\mathrm{CT}$ & $\mathrm{ES}$ & $\mathrm{CT}$ & $\mathrm{ES}$ & $\mathrm{CT}$ & $\overline{\mathrm{ES}}$ \\
\hline $\mathrm{C} 1 \mathrm{ctrl}^{1}$ vs all & $82.5^{*}$ & $14.3^{*}$ & $226.0^{*}$ & $21.6^{*}$ & $237.0^{*}$ & $19.5^{*}$ & $238.5^{*}$ & $29.8^{*}$ & $241.0^{*}$ & $26.0 *$ & $303.0^{*}$ & $34.2^{*}$ \\
\hline $\mathrm{C} 2 \operatorname{ctrl} v s \mathrm{std}^{2}$ & $\mathrm{~ns}$ & $\mathrm{~ns}$ & $\mathrm{~ns}$ & $\mathrm{~ns}$ & $\mathrm{~ns}$ & $\mathrm{~ns}$ & ns & $1.9^{*}$ & $\mathrm{~ns}$ & ns & $\mathrm{ns}$ & ns \\
\hline $\mathrm{C} 3 \mathrm{ctrl} v s \mathrm{cplt}^{3}$ & $23.0 *$ & $3.5^{*}$ & $58.0^{*}$ & $4.0^{*}$ & $59.5^{*}$ & $4.5^{*}$ & $58.0^{*}$ & $6.6^{*}$ & $61.5^{*}$ & $7.0^{*}$ & $69.5^{*}$ & $8.3^{*}$ \\
\hline $\mathrm{C} 4 \operatorname{std} v s\left(\operatorname{std}+\mathrm{I}^{1}\right)$ & ns & $\mathrm{ns}$ & $\mathrm{ns}$ & $\mathrm{ns}$ & ns & $\mathrm{ns}$ & ns & ns & ns & ns & ns & ns \\
\hline $\mathrm{C} 5 \operatorname{std} v s\left(\operatorname{std}+\mathrm{M}^{1}\right)$ & $12.0^{*}$ & $\mathrm{~ns}$ & $31.5^{*}$ & $\mathrm{~ns}$ & $30.5^{*}$ & $\mathrm{~ns}$ & $33.5^{*}$ & ns & $30.0^{*}$ & $1.9 *$ & $\mathrm{~ns}$ & ns \\
\hline $\mathrm{C} 6 \operatorname{std} v s\left(\mathrm{std}+\mathrm{B}^{1}\right)$ & $\mathrm{ns}$ & $\mathrm{ns}$ & $\mathrm{ns}$ & $\mathrm{ns}$ & $\mathrm{ns}$ & $\mathrm{ns}$ & $13.0^{*}$ & ns & ns & ns & $\mathrm{ns}$ & ns \\
\hline $\mathrm{C} 7(\mathrm{std}+\mathrm{I}) v s(\mathrm{std}+\mathrm{I}+\mathrm{M})$ & $18.5^{*}$ & $2.3 *$ & $28.5^{*}$ & $2.0^{*}$ & $33.0^{*}$ & $2.4^{*}$ & $40.5^{*}$ & $2.1 *$ & $38.5^{*}$ & $2.5^{*}$ & $37.0^{*}$ & $3.2 *$ \\
\hline $\mathrm{C} 8(\operatorname{std}+\mathrm{I}) v s(\operatorname{std}+\mathrm{I}+\mathrm{B})$ & ns & ns & ns & ns & $11.0^{*}$ & ns & $13.5^{*}$ & ns & $12.0^{*}$ & ns & $20.0 *$ & $3.0 *$ \\
\hline $\mathrm{C} 9(\mathrm{std}+\mathrm{M}) v s(\mathrm{std}+\mathrm{I}+\mathrm{M})$ & ns & ns & ns & ns & ns & ns & ns & ns & ns & ns & ns & ns \\
\hline $\mathrm{C} 10(\operatorname{std}+\mathrm{M}) v s(\mathrm{std}+\mathrm{M}+\mathrm{B})$ & $13.5^{*}$ & ns & $25.0 *$ & $1.9^{*}$ & $25.5^{*}$ & ns & $25.5^{*}$ & $2.5^{*}$ & $28.0^{*}$ & $2.6^{*}$ & $17.5^{*}$ & $3.9^{*}$ \\
\hline $\mathrm{C} 11(\mathrm{std}+\mathrm{B}) v s(\mathrm{std}+\mathrm{I}+\mathrm{B})$ & ns & ns & ns & ns & $2.5^{*}$ & ns & ns & ns & ns & ns & ns & ns \\
\hline $\mathrm{C} 12(\operatorname{std}+\mathrm{B}) v s(\mathrm{std}+\mathrm{M}+\mathrm{B})$ & $22.0^{*}$ & $2.1 *$ & $47.5^{*}$ & $2.5^{*}$ & $47.5^{*}$ & $1.8^{*}$ & $46.0^{*}$ & $3.0 *$ & $48.5^{*}$ & $3.3^{*}$ & $51.0^{*}$ & $6.5^{*}$ \\
\hline $\mathrm{C} 13(\mathrm{std}+\mathrm{I}+\mathrm{M}) v s$ cplt & ns & ns & $24.0 *$ & ns & $21.0^{*}$ & ns & $14.5^{*}$ & $2.4^{*}$ & $18.5^{*}$ & $3.3^{*}$ & $22.0 *$ & $4.2 *$ \\
\hline $\mathrm{C} 14(\mathrm{std}+\mathrm{I}+\mathrm{B}) v s \mathrm{cplt}$ & $20.0^{*}$ & $2.4 *$ & $42.5^{*}$ & $1.9 *$ & $43.0^{*}$ & ns & $41.5^{*}$ & $4.3 *$ & $45.0 *$ & $4.5^{*}$ & $39.0^{*}$ & $4.5^{*}$ \\
\hline $\mathrm{C} 15(\mathrm{std}+\mathrm{M}+\mathrm{B}) v s \mathrm{cplt}$ & ns & ns & ns & ns & ns & ns & ns & ns & ns & ns & ns & ns \\
\hline
\end{tabular}

${ }^{1} \mathrm{ctrl}=$ control; $\mathrm{I}=$ inoculant; $\mathrm{M}=$ micronutrient; $\mathrm{B}=$ bioregulator; ${ }^{2} \mathrm{std}=$ standard (fungicide + insecticide); ${ }^{3}$ cplt $=$ complete $($ fungicide + insecticide + inoculant + micronutrient + bioregulator).

* significant at $5 \%$ probability by the Bonferroni “ $\mathrm{t}$ " test $(\mathrm{p}<0.05)$; ns non significant $(\mathrm{p}>0.05)$. 
germination of the treated seeds were maintained, regardless of the treatment received, during the said periods.

However, because the $\mathrm{C} 1$ contrast involves a large group of treatments, the results were influenced by the means of those treatments that affected the quality of the seeds with greater intensity. This fact is clearly observed when comparing the results of contrast $\mathrm{C} 2$, which compares the control with the standard treatment (fungicide + insecticide), indicating that there were no significant differences for all variables in all periods studied. In this sense, maize seeds treated with fludioxonil + metalaxyl-M + thiamethoxam can be stored for up to 90 days, maintaining the physiological quality. These results showed that besides the treatment of maize seeds with fungicide and insecticide being consolidated, it is also an effective practice. Results observed by Dan et al. (2011) also indicate adequate levels of germination and vigour with the treatment of soybean seeds, using the same insecticide. In relation to the fungicide fludioxonil + metalaxyl-M, Resende et al. (2005) verified the efficiency in preserving the vigour for up to three months of storage. On the other hand, Deuner et al. (2014) reported that treatments containing thiametoxam showed a greater reduction in maize seed vigour during storage period compared to treatments with deltamethrin, pirimiphos-methyl, fludioxonil and fenitrothion. These results can be explained by Tonin et al. (2014) who concluded that the physiological quality of treated maize seeds is dependent on the hybrid used.

The results of contrast $\mathrm{C} 3$, which compares the control with the complete treatment, indicate that there were significant differences for all the characteristics, in all periods, except for germination in the period zero. Thus, the addition of all products (fungicide + insecticide + inoculant + micronutrient + bioregulator) and, consequently, higher spray volume (3200 mL. $100 \mathrm{~kg}^{-1}$ of seeds), reduced seed vigour immediately after treatment. This indicates that the complete treatment can maintain germination, however the seed vigour is decreased.

When analyzing the contrast results that isolate the effect of the inoculant, either in combination with the standard treatment (contrast $\mathrm{C} 4$ ), with the standard + micronutrient (contrast C9), standard + bioregulator (contrast C11) or standard + bioregulator + micronutrient (contrast $\mathrm{C} 15$ ), there were no significant differences $(p>0.05)$ for all variables at all storage periods. Thus, the addition of the inoculant did not affect the quality of the maize seeds throughout 90 days of storage. This fact can be justified by the inoculant being a biological product and not a synthetic molecule.

On the effect of the addition of bioregulator on seed treatment, for the C6 (in comparison with the standard treatment) and $\mathrm{C} 8$ contrasts (comparison with the standard + inoculant), no significant differences were observed for the
GT, PL and ES. Seed germination, vigour and emergence were not affected by these combinations during the entire storage period, except for PL and ES at 90 days. However, from the 15th day for CT, there were significant differences indicating that seed vigour is affected by the addition of bioregulator after 15 days of storage. Results obtained by Dan et al. (2014) demonstrate that, for periods of up to 60 days of storage, the bioregulator was able to maintain the initial performance of maize seeds. Also, Castro and Vieira (2001) observed efficiency in the application of bioregulator in seed treatment, resulting in a greater number of normal seedlings on the germinative performance of maize seeds.

For contrast $\mathrm{C} 10$, in comparison with the standard treatment + micronutrients, when the bioregulator was added, significant differences were observed after 15 days of storage, for most variables. Thus, it is inferred that in the presence of micronutrients, vigour, germination and emergence are affected by this combination, after the storage period quoted. In contrast, for contrast $\mathrm{C} 13$, in comparison with the standard treatment + inoculant + micronutrients, no significant differences for most variables up to 30 days of storage were noticed. After this period, the addition of the bioregulator, which resulted in the complete treatment, negatively affected the physiological quality of maize seeds.

The addition of micronutrients with the standard treatment (contrast C5) did not influence germination and emergence of seeds, based on the results of GT and SE variables, except for 60 days of storage for the last variable. Thus, the micronutrients did not lead to the reduction of germination and emergence during storage. However, the vigour evaluated by the CT variable, simulating cold conditions with high humidity, presented a significant reduction from period zero.

Still on micronutrients, significant differences were observed for $\mathrm{C} 7$ (comparison of micronutrients with standard + inoculant), C12 (comparison of micronutrients with standard + bioregulator) and C14 (comparison with standard + inoculant + bioregulator). For all of these comparisons, the $\mathrm{CT}$ and SE variables were affected in most storage periods. This indicates that seed vigour, expressed by the percentage of normal seedlings or by the velocity index was reduced when the micronutrients were added to these seed treatments.

Variations were observed in germination and emergence according to the combination studied. The micronutrients in the presence of the inoculant maintained the germination until 60 days. On the other hand, in the presence of bioregulator or of all the products, with consequent increase of spray volume, both germination and emergence were maintained only in period zero.

For all the contrasts that evaluate the effect of micronutrients, the results of seedling length presented variations in the storage 
periods. However, it is possible to infer that, in general, the product reduced the size of the seedlings. The addition of micronutrients to maize seed treatment, mainly in the presence of bioregulator, caused phytotoxicity, reducing vigour and germination of the seeds in a greater intensity. Combinations of boron and zinc can be harmful to normal seedlings formation and to germination speed (Acha et al., 2016).

However, disagreeing with the results of the present study, maize seeds treated with copper were not affected during four months of storage (Dias et al., 2015). Similarly, an increase in grain yield of maize, can be obtained when using zinc sulfate (Harris et al., 2007). Contradictory results observed in the treatment of seeds with micronutrients are possibly due to the formulation of the nutrient used, the dosage, the formulation combinations, the species, the cultivar and the initial quality of the treated seeds (Farooq et al., 2012).

Regression analysis was performed to evaluate the behaviour of seed treatments over the storage periods (Figure 1). The T4 (standard treatment + micronutrients), T6 (standard treatment + inoculant + micronutrient), T8 (standard treatment + micronutrient + bioregulator) and T9 treatments (complete treatment) affected vigour the most presenting greater reductions, compared to the other treatments, even in period zero. Moreover, it is possible to infer that the deleterious effect of the solution composition prevailed and not the volume, since these treatments constitute different spray volumes. Thus, another approach should be used to quantify the real effect of spray volume, such as characteristics and methodologies that isolate the effect of the aqueous solution.

In relation to the germination (GT), regressions were non-significant to T1 (control), T2 (standard treatment), T3 (standard + inoculant), T5 (standard + bioregulator) and T7 (standard + inoculant + bioregulator) (Figure 2), ie germination was maintained throughout the storage period. For treatments T4 (standard + micronutrients), T6 (standard + inoculant + micronutrient), T8 (standard + micronutrient + bioregulator) and T9 (complete treatment), the models were significant and with linear adjustments. The reductions were in $0.07 \%, 0.13 \%$, $0.22 \%$ and $0.22 \%$, for each storage day, respectively. Again, the addition of the micronutrients to the solution possibly caused a notable phytotoxic effect throughout the storage period, drastically reducing the germinative capacity of seeds. In addition, the deleterious effect of the solution composition prevailed, not the volume, since these treatments constitute different spray volumes. The results of the regression analysis also allow us to infer that germination up to 45 days of storage for all treatments remained within the standards of Normative Instruction $n^{\circ} .25$, of the Ministry of Agriculture, Livestock and Supply, being equal to or above $85 \%$ (Brasil, 2005). After this period, only treatments $\mathrm{T} 8$ and $\mathrm{T} 9$ presented germination below the standard for commercialization.

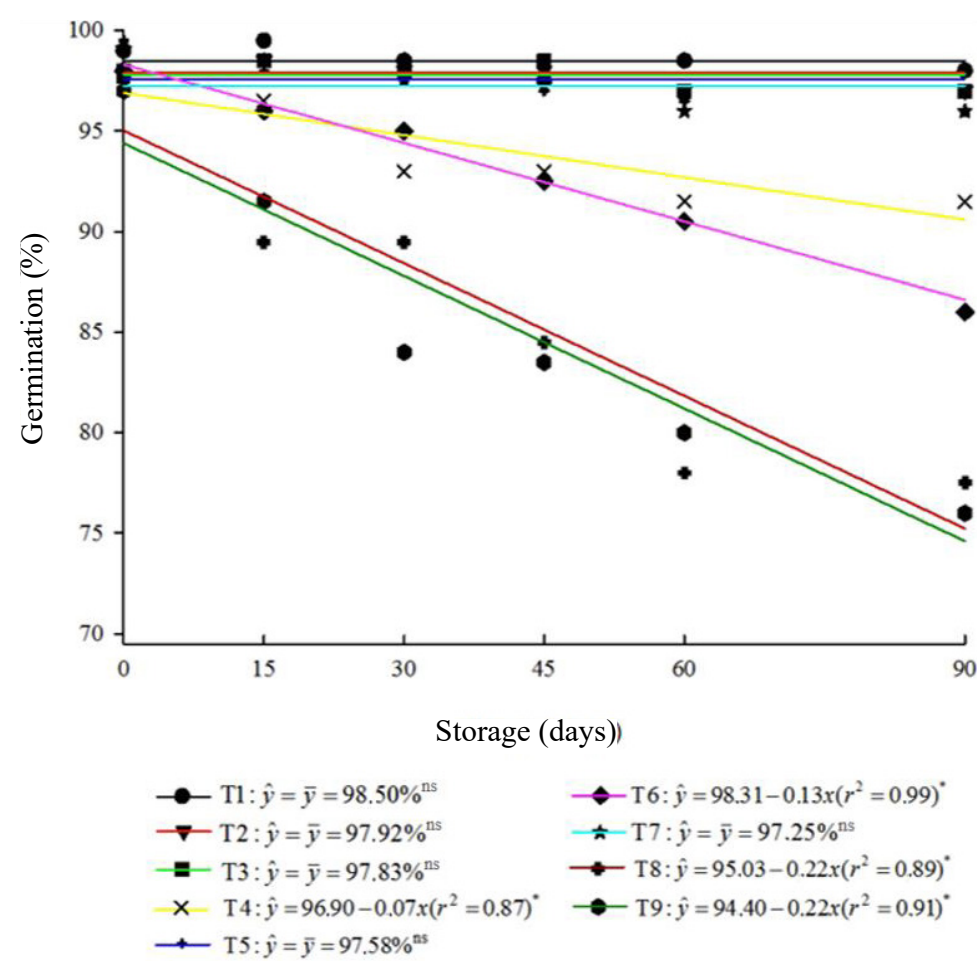

Figure 1. Percentage of normal seedlings in the germination test as a function of storage periods. *significant regression at $5 \%$ probability $(\mathrm{p}<0.05)$; ns non significant regression $(\mathrm{p}>0.05)$. 


\section{Conclusions}

The seed vigour of the maize hybrid 'CD 324 PRO' was reduced by the treatments studied. The reduction intensity is dependent on the product used in the treatment and storage period. The addition of micronutrients resulted in a higher phytotoxic effect on the seeds compared to other products, from period zero and increasing over time. Treatments with fungicide, insecticide and inoculant were feasible, as they maintained acceptable levels of vigour, germination and emergence. All seed treatments did not interfere with seed germination for up to 45 days of storage. Finally, the treatment of maize seeds with complete treatment and $3200 \mathrm{~mL} .100 \mathrm{~kg}^{-1}$ of seeds can maintain germination however seed vigour is decreased.

\section{References}

ACHA, A.J.; VIEIRA, H.D.; FREITAS, M.S.M. Perennial soybean seeds coated with high doses of boron and zinc. African Journal of Biotechnology, v.15, n.37, p.1998-2005, 2016. https://www.ajol. info/index.php/ajb/article/viewFile/144449/134095

ALVES, V.M.; JULIATTI, F.C. Tratamento de sementes de híbridos de milho com fluquinconazol. Bioscience Journal, v.26, n.6, p.930939, 2010. http://www.seer.ufu.br/index.php/biosciencejournal/ article/view/7240/6614

AVELAR, S.A.G.; BAUDET, L.; PESKE, S.T.; LUDWIG, M.P.; RIGO, G.A.; CRIZEL, R.L.; OLIVEIRA, S. Armazenamento de sementes de soja tratadas com fungicida, inseticida e micronutriente e recobertas com polímeros líquido e em pó. Ciencia Rural, v.41, n.10, p.1719-1725, 2011. http://www.scielo.br/pdf/cr/v41n10/ a13211 cr4818.pdf

BARROS, A.S.R.; DIAS, M.C.L.L.; CÍCERO, S.M.; KRZYZANOWSKI, F.C. Teste de frio. In: KRZYZANOWSKI, F.C.; VIEIRA, R.D.; FRANÇA-NETO, J.B. (Eds.). Vigor de sementes: conceitos e testes. Londrina: ABRATES, 1999. p.1-5.

BRASIL. Ministério daAgricultura, PecuáriaeAbastecimento. Regras para análise de sementes. Ministério da Agricultura, Pecuária e Abastecimento. Secretaria de Defesa Agropecuária. Brasília: MAPA/ACS, 2009. 395p. http://www.agricultura.gov.br/arq_editor/ file/2946_regras_analise_sementes.pdf

BRASIL. Instrução Normativa n. 25, de 16 de dezembro de 2005. Diário Oficial da União, Brasília, DF, 16 dez. 2005. p.18.

CASTRO, P.R.C.; VIEIRA, E.L. Aplicações de reguladores vegetais na agricultura tropical. Guaíba: Livraria e Editora Agropecuária, 2001. 132 p.

CASTRO, G.S.A; BOGIANI, J.C.; SILVA, M.G.; GAZOLA, E.; ROSOLEM, C.A.; Tratamento de sementes de soja com inseticidas e um bioestimulante. Pesquisa Agropecuária Brasileira, v.43, n.10, p.1311-1318, 2008. http://www.scielo.br/pdf/pab/v43n10/08.pdf
DAN, L.G.M.; BRACCINI, A.L.; PICCININ, G.G.; DAN, H.A.; RICCI, T.T.; SCAPIM, C.A. Influence of bioregulator on physiological quality of maize seed during storage. Comunicata Scientiae, v.5, n.3, p.286-294, 2014. https://comunicatascientiae. com.br/comunicata/article/view/373/269

DAN, L.G.M.; DAN, H.A.; BRACCINI, A.L.; ALBRECHT, L.P.; RICCI, T.T.; PICCININ, G.G. Desempenho de sementes de soja tratadas com inseticidas e submetidas a diferentes períodos de

armazenamento. Revista Brasileira de Ciências Agrárias, v.6, n.2, p.215-222, 2011. http://www.agraria.pro.br/sistema/index.php?journal $=$ agraria $\&$ page $=$ article \&op $=$ view $\&$ path $\% 5 \mathrm{~B} \% 5 \mathrm{D}=$ agraria v6i2a939\&path $\% 5 B \% 5 \mathrm{D}=904$

DEUNER, C.; ROSA, K.C.; MENEGHELlO, G.E.; BORGES, C.T.; ALMEIDA, A.D.S.; BOHN, A. Physiological performance during storage of corn seed treated with insecticides and fungicide. Journal of Seed Science, v.36, n.2, p.204-212, 2014. http://www. scielo.br/pdf/jss/v36n2/v36n2a09.pdf

DIAS, M.A.N.; CICERO, S.M.; NOVEMBRE, A.D.L.C. Uptake of seed-applied copper by maize and the effects on seed vigor. Bragantia, v.74, n.3, p.241-246, 2015. http://www.scielo.br/pdf/ brag/v74n3/0006-8705-brag-167844990044.pdf

FAROOQ, M.; WAHID, A.; SIDDIQUE, K.H.M. Micronutrient application through seed treatments: a review. Journal of Soil Science and Plant Nutrition, v.12, n.1, p.125-142, 2012. http://www. scielo.cl/pdf/jsspn/v12n1/art11.pdf

HARRIS, D.; RASHID, A.; MIRAJ, G.; ARIF, M.; SHAH, H. 'Onfarm' seed priming with zinc sulphate solution: A cost effective way to increase the maize yields of resource-poor farmers. Field Crops Research, v.102, n.2, p.119-127, 2007. http://www.sciencedirect. com/science/article/pii/S0378429007000342

MAGUIRE, J.D. Speed of germination aid in selection and evaluation for seedling emergence and vigor. Crop Science, v.2, n2, 1962.

NAKAGAWA, J. Testes de vigor baseados no desempenho das plântulas. In: KRZYZANOWSKI, F.C.; VIEIRA, R.D.; FRANÇANETO, J.B. (Eds.). Vigor de sementes: conceitos e testes. Londrina: ABRATES, 1999. cap.3, p.1-24.

RESENDE, M.L.; PEREIRA, C.E.; OLIVEIRA, J.A.; GUIMARÃES, R.M. Qualidade de sementes de milho (Zea mays) tratadas com fungicida e inoculadas com Trichoderma harzianum. Revista Ciência Agronômica, v.36, n.1, p.60-66, 2005. http://www. ccarevista.ufc.br/seer/index.php/ccarevista/article/view/8/9

SILVA, T.T.A.; VON PINHO, E.V.R.; CARDOSO, D.L.; FERREIRA, C.A.; ALVIM, P.O.; COSTA, A.A.F. Qualidade fisiológica de sementes de milho na presença de bioestimulante. Ciência e Agrotecnologia, v.32, n.3, p.840-846, 2008. http://www. scielo.br/pdf/cagro/v32n3/a21v32n3.pdf

TONIN, R.F.B.; LUCCA FILHO, O.A.; LABBE, L.M.B.; ROSSETO, M. The seed physiological potential of hybrid corn treated with insecticides and store in two environmental conditions. Scientia Agropecuaria, v.5, n.1, p;007-016, 2014. http://www. revistas.unitru.edu.pe/index.php/scientiaagrop/article/view/522/495 